Note

\title{
Validation of a methodology for measuring nutrient digestibility and evaluation of commercial feeds for channel catfish
}

\author{
Renato Eiji Kitagima ${ }^{1}$; Débora Machado Fracalossi \\ ${ }^{1}$ UFSC/CCA - Programa de Pós-Graduação em Aquicultura. \\ ${ }^{2}$ UFSC/CCA - Depto. de Aquicultura, Rod. Admar Gonzaga, 1346 - 88034-001 - Florianópolis, SC - Brasil. \\ *Corresponding author < deboraf@cca.ufsc.br>
}

\begin{abstract}
Channel catfish, a major freshwater aquaculture species in the US, is also farmed in Southern Brazil. However, apparent digestibility coefficients (ADC) of nutrients in commercial feeds available in Brazil for the species are not known. This study aimed at optimizing a methodology for fecal collection and determination of apparent nutrient digestibility for catfish. Pilot trials were carried out to establish gastrointestinal transit, fish density, and time interval between fecal collections. Gastrointestinal transit of dry feed for catfish varied from $11 \mathrm{~h} 30$ to $10 \mathrm{~h} 30$ for 100 and 172-g fish, respectively. Average dry weight of feces produced along a six day period by $99 \mathrm{~g}$ fish was $0.54 \mathrm{~g}$, regardless of stocking density $(10,15$ or 20 fish per 98 $\mathrm{L}$ cage; $p>0.05$ ). Described methodology allowed the collection of average $10.80 \mathrm{~g}$ feces per tank (dry weight) in three days. Feces collected at 1,6 or $12 \mathrm{~h}$ had increased protein digestibility from 1 to $12 \mathrm{~h}$, that is, there was increased protein leaching as the time of feces exposure to water increased. Fecal collection was optimized at 20 fish per tank and $6 \mathrm{~h}$ interval between collections. ADC of protein, energy, and dry matter of four commercial feeds for catfish using the indirect method with the addition of $0.5 \%$ of $\mathrm{Cr}_{2} \mathrm{O}_{3}$ as an inert maker was also evaluated. Crude protein contents of commercial feeds matched manufacturer's specifications but did not yielded the $28 \%$ digestible protein required for adequate channel catfish growth. The digestible protein of commercial feeds ranged from $23.3 \%$ to $25.6 \%$ and digestible energy ranged from 1177 to $1249 \mathrm{~kJ}$ $100 \mathrm{~g}^{-1}$ feed. It is instrumental measuring nutrient digestibility when evaluating commercial feeds.

Key words: nutrient availability, fish nutrition, siluriform fish, channel catfish
\end{abstract}

\section{Validação de um método para medir a digestibilidade de nutrientes e avaliação de rações comerciais para catfish}

\begin{abstract}
RESUMO: O catfish americano, espécie aquícola importante nos Estados Unidos, também é produzido no sul do Brasil. Entretanto, a digestibilidade dos nutrientes das rações disponíveis no Brazil não é conhecida. Nesse estudo otimizou-se a coleta de fezes e a determinação do coeficiente de digestibilidade aparente (CDA) para a espécie. Ensaios pilotos foram conduzidos para determinação do tempo de passagem do alimento no trato digestório, densidade dos peixes e intervalo entre coletas de fezes. $\mathrm{O}$ tempo de passagem variou de $11 \mathrm{~h} 30 \mathrm{a}$ $10 \mathrm{~h} 30 \mathrm{em}$ peixes com peso médio de 100 e $172 \mathrm{~g}$, respectivamente. O peso médio (base seca) das fezes produzidas por peixes (peso médio $99 \mathrm{~g}$ ), em seis dias, foi $0.54 \mathrm{~g}$, independentemente de a densidade ser 10, 15 ou 20 peixes por gaiola $(p>0.05)$. Com esta metodologia foi possível coletar $10.80 \mathrm{~g}$ de fezes (base seca) por tanque em três dias. A digestibilidade da proteína aumentou com intervalos de coleta de fezes de 1,6 e $12 \mathrm{~h}$, indicando aumento na lixiviação deste nutriente à medida que aumentou o tempo de exposição das fezes à água. A coleta de fezes foi otimizada com 20 peixes por tanque e com $6 \mathrm{~h}$ de intervalo entre as coletas. Também foi avaliado o CDA para proteína, energia e matéria seca de rações comerciais para catfish, utilizando-se o método indireto com a adição de $0.5 \%$ de $\mathrm{Cr}_{2} \mathrm{O}_{3}$ como marcador inerte nas dietas. Os conteúdos de proteína bruta das rações comerciais foram similares às especificações dos fabricantes, mas as rações não forneceram $28 \%$ de proteína digestível, necessária para o crescimento adequado da espécie. A proteína digestível nas rações comerciais variou de $23.3 \%$ a $25.6 \%$ e a energia digestível, de 1177 a $1249 \mathrm{~kJ} 100 \mathrm{~g}^{-1}$ de ração. Ressalta-se assim a importância da determinação da digestibilidade dos nutrientes na avaliação de rações comerciais.

Palavras-chave: disponibilidade de nutrientes, nutrição de peixes, siluriformes
\end{abstract}

\section{Introduction}

Channel catfish, Ictalurus punctatus, is a freshwater species native to the Mississippi river delta, United States of America. The Southeastern US states of Mississippi, Alabama, Louisiana, and Arkansas are responsible for most catfish production (NASS, 2008) in the US. In Brazil, catfish is successfully farmed mainly in the Southern Santa Catarina State. However, published data on nutrient digestibility of American ingredients for catfish have limited value for feed formulation in Brazil as a result of variation among ingredients chemical compo-

Sci. Agric. (Piracicaba, Braz.), v.67, n.5, p.611-615, September/October 2010 
sition. Therefore, measuring the nutrient digestibility coefficient of commercial feeds produced in Brazil is essential to evaluate if catfish nutritional requirements for adequate growth and health are being met by the feed industry.

Measurement of dietary nutrient digestibility in fish is mainly accomplished by the indirect method, which allows partial collection of feces but requires the addition of an inert marker in the diet. Several methods for fecal collection have been reported for fish but the most widely used are stripping the final portion of the intestine, dissecting the intestine, or collecting the feces from the water, after evacuation (Belal, 2005). All methods have vantages and disadvantages regarding fecal contamination with endogenous components, stress responses of fish, nutrient leaching or the need to sacrifice laboratorytrained fish.

This study aimed at optimizing fecal collection and validating a methodology to determine dietary nutrient digestibility having channel catfish as biological model. Despite risking nutrient leaching from feces to the water, fecal collection after evacuation and settlement in a collection tube (modified "Guelph" system; Cho et al., 1985) was the method of choice because it imposes less stress responses and does not require sacrificing fish. Gastrointestinal transit, fish stocking density in the feces collection tank, and time between collections were evaluated to optimize fecal collection. Protein, energy and dry matter digestibility of four catfish commercial feed were also evaluated.

\section{Material and Methods}

Pilot trials were carried out to evaluate fecal collection prior the measurement of commercial feed digestibility for catfish: gastrointestinal transit, optimization of fish stocking density at the feces collection tanks, and time interval between feces collection. A digestibility trial was then performed to evaluate the apparent digestibility coefficients (ADC) of protein, energy and dry matter of four commercial catfish feeds.

\section{Gastrointestinal transit}

The time lapse from feed ingestion to fecal evacuation was determined for two, 15-fish groups $(n=2)$ of two weight ( \pm standard errors) classes: $99.60 \pm 20.8 \mathrm{~g}$ and $171.63 \pm 15.0 \mathrm{~g}$. Groups were housed in 98 -L cages within 1000-L, indoor feeding tanks, connected to a water recirculation system with controlled temperature, aeration, and a 12-h photoperiod.

Fish were fed an extruded, commercial feed containing $27.33 \%$ crude protein $(\mathrm{CP})$ to apparent satiety twice a day (10h00 and 16h00) for seven days prior to feces collection. From the eight day forth, fish were fed the same commercial feed added of $1 \%$ chromic oxide as inert marker. Feed was ground and repelleted for incorporation of marker. One hour after the second daily feeding, cages containing the four groups of fish were transferred to the 120-L conical, thoroughly cleaned feces collection tanks, and feces were then collected every 30 $\min$ for $26 \mathrm{~h}$. The time lapse between feeding the marked diet and the evacuation of marked feces indicated the gastrointestinal transit. Feces settled into a $50-\mathrm{mL}$ tube placed at the bottom of the conical collection tank. The whole content of each $50-\mathrm{mL}$ tube was centrifuged at $2,300 \times g$ for $5 \mathrm{~min}$. The supernatant was discarded and the fecal pellet dried at $105^{\circ} \mathrm{C}$ until constant weight (approximately $24 \mathrm{~h}$ ). The amount of feces produced was also registered.

Dissolved oxygen, temperature, and $\mathrm{pH}$ were monitored daily in the feces collection tanks and averaged $6.3 \pm 1.0 \mathrm{mg} \mathrm{L}^{-1}, 28.7 \pm 1.6^{\circ} \mathrm{C}$, and $7.18 \pm 0.3$, respectively.

\section{Fish stocking rate at the feces collection tank}

To determine the best fish stocking density for maximum fecal collection, triplicate groups of fish (99.46 \pm $25.4 \mathrm{~g}$ ) were stocked into 98-L cages at 10, 15, or 20 fish per cage and fed as previously described. Daily, at $17 \mathrm{~h} 00$ $\mathrm{h}$ for six days, cages were transferred from the feeding tanks to the feces collection tanks. Feces were then collected for $16 \mathrm{~h}$ after the last feeding. During this period, feces collection tubes were kept iced to prevent microorganism proliferation.

Water quality in the feces collection tanks and feeding tanks were monitored daily and kept at satisfactory conditions for channel catfish (Boyd, 1990): temperature $28.5 \pm 1.8^{\circ} \mathrm{C}$; pH $7.37 \pm 0.4$; dissolved oxygen $7.2 \pm 1$ $\mathrm{mg} \mathrm{L}^{-1}$, and total ammonia $<0.25 \mathrm{mg} \mathrm{L}^{-1}$. Fish were also checked daily for lesions or mortality.

\section{Time interval between feces collection}

To evaluate if the exposure of feces to the water for different time periods would affect protein digestibility, six groups of 20 fish $(113.0 \pm 29 \mathrm{~g})$ were acclimated to the experimental conditions for three days feeding on a commercial diet $(27.33 \%$ CP; $11.40 \%$ ash; $7.60 \%$ lipids; 92.10\% dry matter; $45.76 \%$ N-free extract; $7.94 \%$ crude

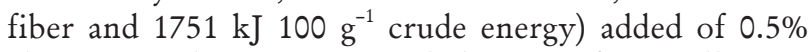
chromic oxide. Time intervals between feces collection were 1,6 , or $12 \mathrm{~h}$. Feces were also collected by dissection directly from the rectum of 100 fish to serve as a negative control for nutrient leaching. Average water temperature in the feces collection tanks was $29.39 \pm$ $0.48^{\circ} \mathrm{C}$, dissolved oxygen $7.53 \pm 0.92 \mathrm{mg} \mathrm{L}^{-1}$ and $\mathrm{pH} 7.62$ \pm 0.10 .

Feces were collected daily until $15 \mathrm{~g}$ of dry matter was obtained. Feces were centrifuged, and dried as described previously. After grinding, feces were frozenstored $\left(-20^{\circ} \mathrm{C}\right)$ until analyses. Feed and feces proximal composition analyses followed AOAC (1999) standard procedures while chromic oxide was analyzed according to methodology proposed by Bremer Neto et al. (2003). Apparent digestibility coefficients of nutrients were determined using the following formula (Cho and Slinger, 1979):

$$
A D C \%=100-\left[100 X\left(\frac{\% \text { marker in feed }}{\% \text { marker in feces }} \times \frac{\% \text { nutrient in feces }}{\% \text { nutriente in feed }}\right)\right]
$$


Commercial feed digestibility for channel catfish

Apparent dry feed digestibility coefficients for protein, energy and dry matter were estimated for four commercial catfish feeds. Each feed was fed to three, 15-fish groups $(113 \pm 19 \mathrm{~g})$. Feces were collected as described previously except that time interval between feces collection was only $6 \mathrm{~h}$.

Fish were fed at $3.5 \%$ body weight according to Lovell (1998). Water quality in the feces collection tank was kept within acceptable range for catfish: temperature $29.5 \pm 0.4^{\circ} \mathrm{C}, \mathrm{pH} 7.5 \pm 0.1$, dissolved oxygen $5.6 \pm$ $0.6 \mathrm{mg} \mathrm{L}^{-1}$ and total ammonia $<0.25 \mathrm{mg} \mathrm{L}^{-1}$ (Boyd, 1990). Proximate composition and chromic oxide analyses in feed and feces were performed as described previously. Proximate compositions of commercial feeds are summarized in Table 1. All four commercial feeds were grinded and sieved $(600 \mu \mathrm{m})$ and thoroughly mixed with $0.5 \%$ chromic oxide using a twin-shell blender. Thirty percent $(\mathrm{w} / \mathrm{w})$ of tepid water was added and the mesh was pressed through a $5 \mathrm{~mm}$ dye. Resulting pellets were dried for $12 \mathrm{~h}$ at $55^{\circ} \mathrm{C}$.

\section{Statistical analyses}

Data were submitted to one-way ANOVA followed by Tukey test $(\alpha=0.05)$. A completely randomized design was used for all trials except for the commercial feed digestibility trial, where a completely randomized block design was adopted with three replicates run over time. In the stocking density trial, a polynomial regression between the total amounts of feces collected over time was used to evaluate effects of fish handling on the amount of feces produced.

\section{Results and Discussion}

\section{Gastrointestinal transit}

Time lapse from feed ingestion to feces evacuation was $11 \mathrm{hh} 30$ and $10 \mathrm{~h} 30$ for 99.60 -g and 171.63 -g fish, respectively. Peaks of fecal production were observed at $12 \mathrm{~h} 30$ and $13 \mathrm{~h} 00$ after first and second feeding, respectively, for the smaller fish and at $11 \mathrm{~h} 30$ and $14 \mathrm{~h} 00$ for the bigger fish (Figure 1). Therefore, feces collection can initiate from 8 to $10 \mathrm{~h}$ after first feeding when

Table 1 - Commercial feed proximal composition (dry basis).

\begin{tabular}{lccccccc}
\hline Commercial Feed & Crude Protein & Ash & Ether Extract & Moisture & N-free Extract & Crude Fiber & Crude Energy \\
\hline & -15.4 & 15.5 & 9.1 & 5.9 & 39.7 & 7.3 & 1717 \\
A & 28.2 & 8.5 & 6.6 & 5.7 & 46.7 & 7.0 & 1796 \\
B & 31.4 & 9.4 & 7.1 & 7.2 & 44.5 & 7.6 & 1799 \\
C & 30.9 & 10.0 & 6.4 & 6.0 & 45.3 & 7.4 & 1781 \\
D & & & & & &
\end{tabular}

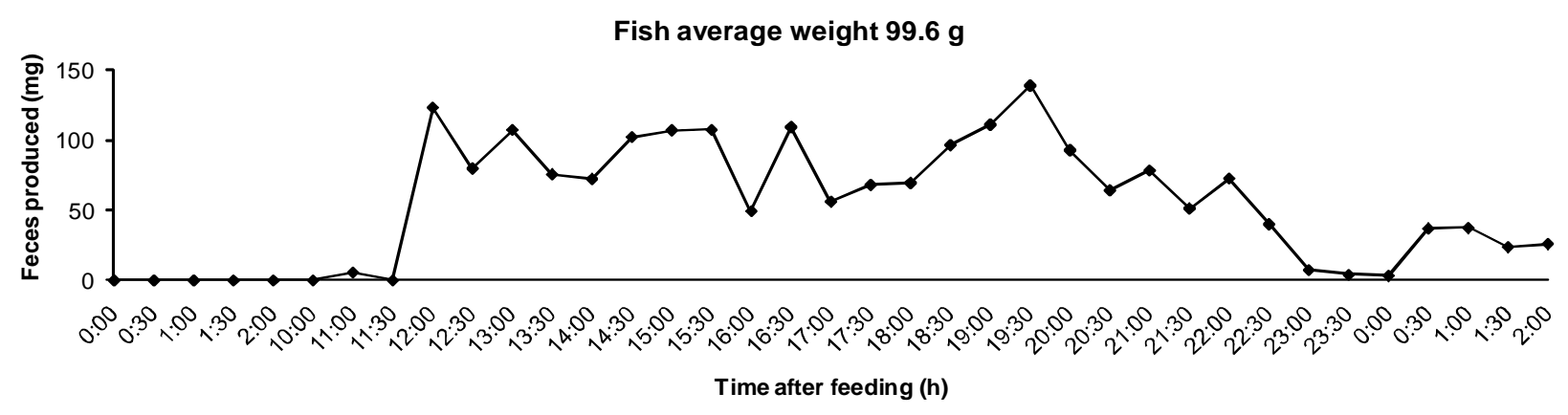

Fish average weight $171.63 \mathrm{~g}$

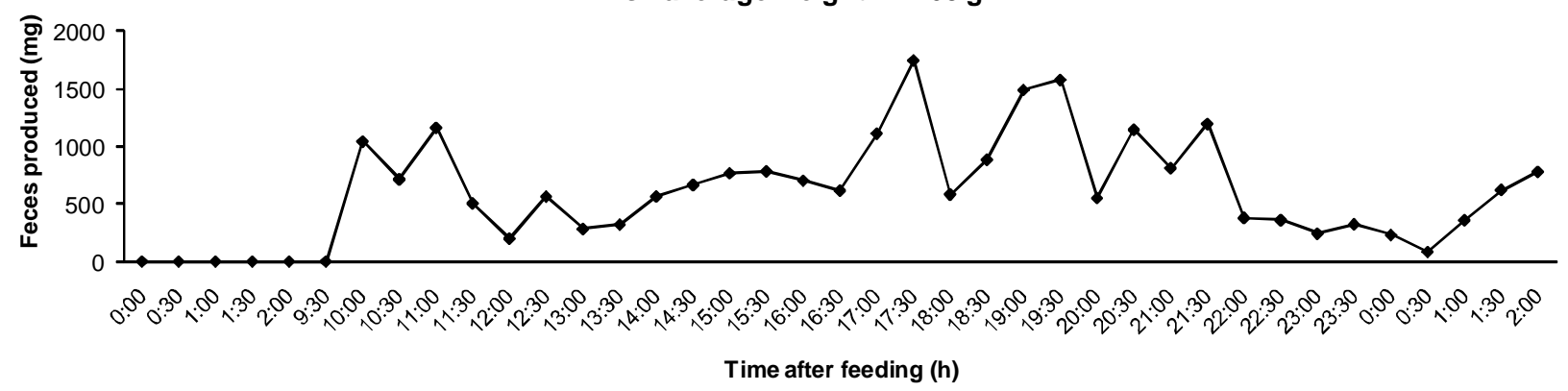

Figure 1 - Time of feed passage through fish digestive tract. Fish average weights were $99.6 \mathrm{~g}$ and $171.63 \mathrm{~g}$. 
water temperature is $28.70^{\circ} \mathrm{C}$ and two feedings are carried out $6 \mathrm{~h}$ apart. Changes in feeding frequency or water temperature can affect feed digestibility, as reported for rainbow trout Oncorbynchus mykiss and common carp Cyprinus carpio (Yamamoto et al., 2007). Increased gastrointestinal transit time was reported for catfish when water temperature was above $26^{\circ} \mathrm{C}$ (NRC, 1993), but nutrient digestibility was not affected.

\section{Fish stocking rate for collection of feces}

Average dry weight of feces collected along a 6-day period from $99.46-\mathrm{g}$ fish was $0.54 \mathrm{~g}$ regardless of stocking density $(p>0.05)$. Fish produced $0.44 \pm 0.15 \mathrm{~g}, 0.57$ $\pm 0.04 \mathrm{~g}$, and $0.61 \pm 0.09 \mathrm{~g}$ of dry feces, at stocking rates 10,15 or 20 fish per cage, respectively. Despite producing similar amount of feces, fish stocked at the higher and intermediate densities showed less signs of distress, ingesting pellets as soon as they reached the water, while fish at the lower stocking rate only ingested feed after pellets had reached the bottom of the tank.

There was a decrease in the amount of feces produced during the 6-day collection period (Figure 2). Transferring fish daily between feeding and feces collection tanks probably caused decreased feed consumption; however, feed consumption was not quantified in this trial. Therefore, for the subsequent trials, the feces collection period was limited to three days.

\section{Time interval between feces collection}

There was an increase in protein ADC between feces collected at 1-h and 12-h intervals indicating sizable protein leaching after feces were in contact with water (Figure 3). The highest protein leaching occurred within the first hour after feces evacuation. Therefore, collection of feces by dissection from the rectum, just before evacuation, could provide a more precise measurement of nutrient digestibility. However, contamination with endogenous compounds and the need to dissect the fish for feces collection are considerable disadvantages of this feces collection method. Additionally, McLean et al. (1999) indicated that protein and peptide are absorbed in the distal intestine and rectum of several fish species. Therefore, feces collection at the distal portion of the intestine or rectum before evacuation could un-

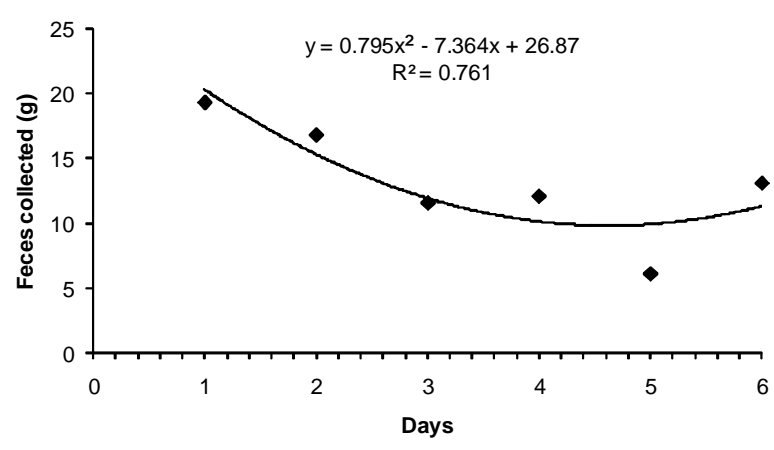

Figure 2 - Total amount of feces collected during six days.

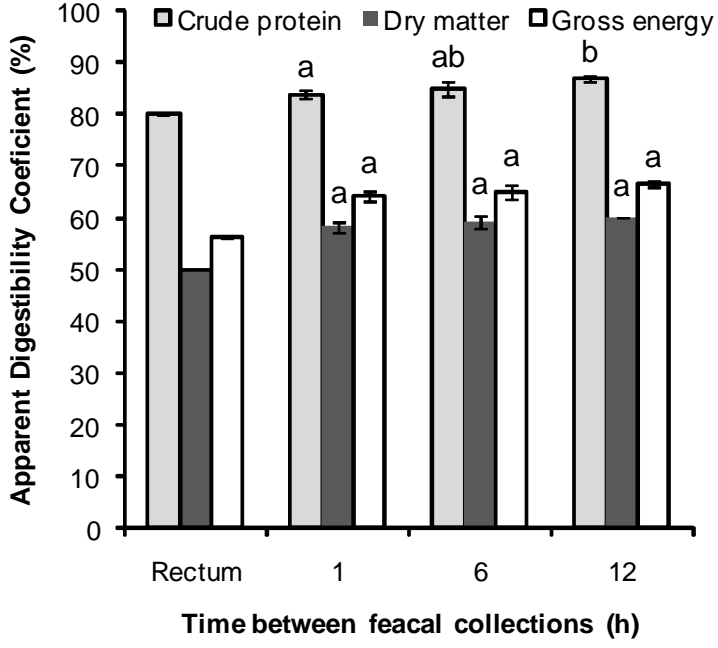

Figure 3 - Nutrient ADC in feces collected at the rectum (by dissection) or after evacuation and settlement into a collection tube at 1,6 , or $12 \mathrm{~h}$ collection intervals. Different letters above same color bars indicate mean difference $(p<0.05)$.

derestimate nutrient digestibility. Furthermore, the rectum, which can be easily identified by the presence of a sphincter in channel catfish (Grizzle and Rogers, 1976), represents a small portion of the distal intestine, and therefore yielding small amounts of feces per fish. As a matter of fact, one hundred fish $(100 \mathrm{~g})$ were dissected to yield only $8.0 \mathrm{~g}$ of dried feces from the rectum. Abimorad and Carneiro (2004) also pointed out the small amount of feces as a disadvantage of collecting feces by dissection from the rectum in similar study with pacu (Piaractus mesopotamicus). However, no differences on protein digestibility were observed in that study when feces were collected by stripping, settlement after $8 \mathrm{~h}$ or dissection. Thus, considering the small magnitude of protein ADC increase observed in the present study between $1 \mathrm{~h}$ and $6 \mathrm{~h}$ and that labor is reduced when collecting feces every $6 \mathrm{~h}$, it is recommended that the time lapse between feces collection should not exceed $6 \mathrm{~h}$.

Digestibility of commercial feed for channel catfish

The previous trials aimed at optimizing the fecal collection for the commercial diet digestibility trial. Protein $\mathrm{ADC}$ for feed $\mathrm{D}(76.5 \%)$ was lower than for the other commercial feeds. Energy ADC for feed A $(72.8 \%)$ was higher than for feed $\mathrm{C}(66.5 \%)$ and $\mathrm{D}(66.1 \%)$ but similar to the one determined for feed B (68.5\%) (Figure 4). Proximate composition of the commercial diets is presented in Table 1. Commercial feeds had similar crude energy contents (1717 to $1796 \mathrm{~kJ} 100 \mathrm{~g}^{-1}$ ) but crude protein $(28.4$ to $31.4 \%)$ and ether extract (39.7 to $46.7 \%)$ contents showed higher variation. However, only the protein digestible fraction (Table 2) was different among commercial feeds.

Pond studies with channel catfish indicate that the digestible protein concentration for grow-out feeds should be $28.0 \%$. Channel catfish fed diets containing 
Table 2 - Nutrient digestible fraction in four commercial feed for channel catfish ${ }^{c}$.

\begin{tabular}{lcccc}
\hline Commercial Feed & Digestible Protein (DP) & Digestible Dry Matter & Digestible Energy $(\mathrm{DE})$ & DE DP-1 \\
\hline & $23.3 \mathrm{~b}$ & $67.8 \mathrm{a}$ & $1249 \mathrm{a}$ & 12.8 \\
A & $25.6 \mathrm{a}$ & $67.8 \mathrm{a}$ & $1230 \mathrm{a}$ & 11.5 \\
B & $25.4 \mathrm{a}$ & $65.1 \mathrm{a}$ & $1196 \mathrm{a}$ & 11.3 \\
C & $23.7 \mathrm{~b}$ & $66.5 \mathrm{a}$ & $1177 \mathrm{a}$ & 11.9 \\
D & & &
\end{tabular}

a,b Different letters within a column indicate difference $(p<0.05) .{ }^{c}$ Nutrient digestible fraction $=($ ADC X \% nutrient in the diet $)$ $100^{-1}$

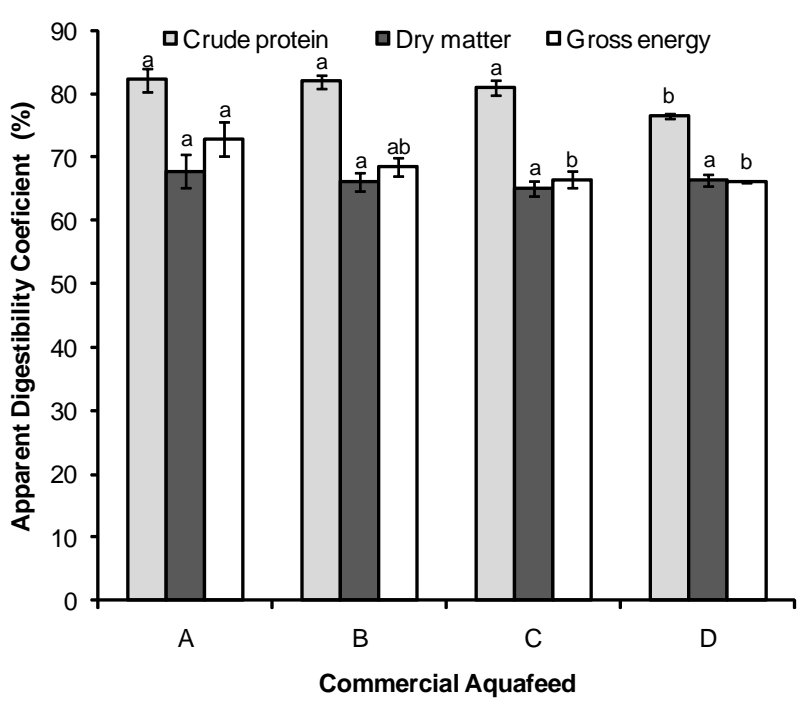

Figure 4 - Apparent digestibility coefficient for protein, energy and dry matter of four catfish commercial feeds. Different letters above same color bars indicate difference $(p<0.05)$.

$24 \%$ crude protein to satiation showed good growth but accumulated body fat when compared to fish fed 28.0 and $32.0 \%$ crude protein, mainly because of the lower energy to protein ratio of the latter diets ( $\mathrm{Li}$ et al., 2004). However, higher dietary protein concentrations (32.0 to $36.0 \%$ ) could be required if catfish are not fed to satiation (NRC, 1993). Table 2 presents the digestible energy to digestible protein ratio of the commercial feeds. This ratio is higher in feeds $\mathrm{A}$ and $\mathrm{D}$, indicating a potential for body fat accumulation.

Feed formulations for catfish in Brazil rely greatly on data from ingredient proximate composition tables. However, there is a noticeable variation in nutrient digestibility among commercial feeds. This variation could result from the ingredients used to formulate the commercial feeds as well as to the particular feed processing conditions adopted by each feed manufacturer. Therefore, it is recommended that digestibility trials be performed periodically to predict ingredient and commercial feed digestibility. Knowledge about ingredient digestibility will allow a more precise diet formulation by feed manufacturers. On the other hand, knowledge of commercial feed digestibility will help fish farmers to evaluate the cost-effectiveness of the commercially available feeds.

\section{References}

Abimorad, E.G.; Carneiro, D.J. 2004. Fecal Collection Methods and Determination of Crude Protein and of Gross Energy Digestibility Coefficients of Feedstuffs for Pacu, Piaractus mesopotamicus (Holmberg, 1887). Revista Brasileira de Zootecnia 33: 1101-1109. (in Portuguese, with abstract in English).

Association of Official Analytical Chemists [AOAC]. 1999. Official Methods of Analysis of AOAC. 16ed. AOAC, Washington, D.C., USA.

Belal, I.E.H. 2005. A review of some fish nutrition methodologies. Biosourse Technology 96: 395-402.

Boyd, C. 1990. Water Quality in Ponds for Aquaculture. Birmingham Publishing, London, England.

Bremer Neto, H.; Graner, C.A.F.; Pezzato, L.E.; Padovani, C.R.; Cantelmo, O.A. 2003. Reduction in Chromium (III) Oxide Level as an External Marker. Revista Brasileira de Zootecnia 32: 249255 (in Portuguese, with abstract in English).

Cho C.Y.; Slinger, S.J. 1979. Apparent digestibility measurement in feedstuffs for rainbow trout. p.239-247. In: Halver, J.E.; Tiews, K., eds. 1979. Proceedings of the World Symposium of Finfish Nutrition and Fishfeed Technology. Berlin, Germany.

Cho, C.Y.; Cowey, C.B.; Watanabe T. 1985. Proceedings of the Finfish nutrition in Asia: Methodological approaches to research and development. 154 p. IDRC, Ottawa, ON, CA, Canada.

Grizzle, J.M.; Rogers, W.A. 1976. Anatomy \& Histology of the Channel Catfish. Auburn University, Auburn, AL, USA.

Li, M.H.; Robinson, E.H.; Manning, B.B. 2004. Nutrition. p. 279323. In: Tucker, C.S.; Hargreaves, J.A., eds. Biology and culture of channel catfish. Elsevier, Amsterdan, Netherlands.

Lovell, R.T. 1998. Nutrition and Feeding of Fish. 2ed. Kluwer, Academic Press, Boston, MA, USA.

McLean E.; Rønsholdt, B.; Sten, C.; Najamuddin, A. 1999. Gastrointestinal delivery of peptide and protein drugs to aquacultured teleosts. Aquaculture 177: 231-247.

National Agricultural Statistics Service [NASS]. 2008. Catfish Production. USDA, Washington, D.C., USA.

National Research Council. [NRC]. 1993. Nutrient Requirements of Fish. National Academy Press, Washington, D.C., USA.

Yamamoto, T; Shima, T; Furuita, H.; Sugita, T.; Suzuki, N. 2007. Effects of feeding time, water temperature, feeding frequency and dietary composition on apparent nutrient digestibility in rainbow trout Oncorbynchus mykiss and common carp Cyprinus carpio. Fisheries Science $73: 161-170$.

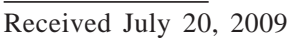

Accepted April 13, 2010 